\title{
A Conceptual Framework for Sustainability in Islamic Architecture: The Significance of the Concepts of Man and the Environment
}

\author{
Assoc. Prof. Dr. Spahic Omer
}

International Islamic University Malaysia

\begin{abstract}
In this paper, I have identified and briefly examined two Islamic concepts which constitute the nucleus of the conceptual framework for sustainability in Islamic architecture. The two concepts are: 1) man as the vicegerent (khalifah) on earth, and 2) the natural environment as both a field and means for man's vicegerency mission. Central to the paper are the following themes: 1) the meaning and significance of Islamic architecture; 2) the position and role of man on earth;3) peaceful and accountable (sustainable) coexistence with the environment; and 4) the implications of the Islamic concepts of man and the environment or sustainability in Islamic architecture. The paper aims to increase awareness, both of the professionals and general public, as to the importance of the theme of sustainability in Islamic architecture by expounding the core of the conceptual basis for the same. The paper presents some general principles and ideas around which a comprehensive theory on sustainability in Islamic architecture, in line with the requirements of the Islamic worldview while fully conforming to the dictates of different circumstances, environments and cultures, can be developed today. The nature of the paper: its content, methodology and conclusions, is a conceptual and philosophical rather than an empirical one. The paper concludes that Islamic architecture, through its multidimensionality embodies the message of Islam. It both facilitates the Muslims' realization of the Islamic purpose and its divine principles on earth and promotes a lifestyle generated by such a philosophy and principles. At the core of Islamic architecture lies function with all of its dimensions: corporeal, cerebral and spiritual. The role of the form is an important one too, but only inasmuch as it supplements and enhances function. Indeed, one of the most recognizable features of Islamic architecture must always be sustainability.
\end{abstract}

Keywords: Islamic Architecture, Islam, Man as the Vicegerent on Earth, the Environment 


\section{Introduction: What is Islamic Architecture?}

The primary characteristic of Islamic architecture is one whose function and form are inspired by the religion of Islam. Islamic architecture is a framework for the implementation of Islam. It facilitates, fosters and stimulates the Muslims' 'ibadah (worship) activities, which, in turn, account for every moment of their earthly lives. Islamic architecture can only come into existence under the aegis of the Islamic perceptions of God, man, nature, life, death and the Hereafter. Practically, Islamic architecture represents the religion of Islam that has been translated onto reality at the hands of Muslims. It also represents the identity of Islamic culture and civilization.

Ibn Abdun, an Andalusian judge from the $12^{\text {th }}$ century, is reported to have said, "As far as architecture is concerned, it is the haven where man's spirit, soul and body find refuge and shelter." In other words, architecture is a container of people's lives. Ibn Qutayba, a Muslim scholar of the $9^{\text {th }}$ century, compared the house, to a shirt, saying that just as the shirt should fit its owner, the house too should suit its dwellers. ${ }^{\text {ii }}$ That is to say, the aesthetic and utilitarian ends of the house must correspond to the needs and capabilities of its users. The two must perfectly suit each other.

The function of Islamic architecture is central on all dimensions: corporeal, cerebral and spiritual. Although form plays a minor part in Islamic architecture; its relevance is a supportive one supplementing and enhancing function. Form is important, but in terms of value and substance it always comes second to function and its wide scope. There must harmony in the ideals that underpin the form of buildings and the ideals that underpin their function, with which the users of buildings must be at ease. Friction between the two is bound to lead to a conflict of some far-reaching psychological proportions in buildings users, in this way, the roles of form become equivalent to the roles of function.

Islamic architecture promotes unity in diversity, the unity of message and purpose, and this too thorough a variation of styles, methods and solutions. Certainly, this renders Islamic architecture as relevant and dynamic, but also consistent and adaptable. It is such a fascinating subject to study, for doing so is not about sheer art and architecture. It is more than that: it is about beholding the Islamic ideology and creating aesthetically pleasing surroundings. It is about witnessing a microcosm of Islamic society, civilization and culture. Islamic architecture is about Islam taking up a manifest form. The identity and vocabulary of Islamic architecture evolved as a means for the fulfilment of the concerns of Muslim societies. Islamic architecture was never an end in itself. It was the container of Islamic culture and civilization reflecting the cultural identity and the level of the Muslims' creative and aesthetic consciousness. Hence, at the core of Islamic architecture must always rest the notion of sustainability.

Architecture, in general, should always be in service to people. It is never to be the other way round, that is to say that architecture should evolve into a hobby or an adventure in the process imposing itself on society while forsaking, or taking 
lightly, people's identities, cultures and the demands of their daily struggles. Architecture, first and foremost, should remain associated with functionality. It should not deviate from its authentic character and stray into the world of excessive invention and abstraction. ${ }^{\text {iii }}$

Alfred Frazer, said about the fundamental nature of Islamic architecture:

The architecture of Islam is the expression of a religion and its view of the world rather than that of a particular people or political or economic system. ${ }^{\text {iv }}$

In the same vein, Titus Burckhardt also wrote that it is not surprising, nor strange, that the most outward manifestation of Islam as a religion and civilization reflects in its own fashion what is most inward in it. The same author further remarked:

If one were to reply to the question 'what is Islam?' by simply pointing to one of the masterpieces of Islamic art such as, for example, the Mosque of Cordova, or that of Ibn Tulun in Cairo, or one of the madrasahs in Samarqand....that reply, summary as it is, would be nonetheless valid, for the art of Islam expresses what its name indicates, and it does so without ambiguity. ${ }^{\mathrm{v}}$

\section{Islam and the Role of Man on Earth}

Man, according to Islam, is a vicegerent on earth entrusted with the honorable task of inhabiting it in accordance with the divine guidance given to him. This terrestrial life serves to man as a test for either elevating his status in the next life, should he abide by the divinely prescribed rules and regulations.

God created man with the primordial natural disposition (fitrah) to thirst for and worship his Creator. God, therefore, knowing best the character of man, his needs and weaknesses, on sending Adam and Eve to earth to assume the duty of vicegerency revealed to them that $\mathrm{He}$ will never forsake them and their progeny. God promised that His guidance and signs will be coming to them, and "Whosoever follows My guidance, on them shall be no fear, nor shall they grieve." vi

God's guidance and signs mean the religion of Islam preached by every prophet from the dawn of mankind and Adam as the first messenger to Muhammad as the last and seal of all messengers. God's divine guidance will enable man to remain strong, sensible, content and "healthy" while on earth, making him, in turn, capable of keeping up the focus of his undertakings on worshipping his Lord in every act, word and thought ('ibadah). God says in the Qur'an that He has created both Jinns and men only that they may serve Him. ${ }^{\text {vi }}$

On the other hand, in the event of man's rejection of God's message and guidance, the repercussions will be costly. The Qur'an says: "But those who reject Faith and belie Our Signs, they shall be Companions of the Fire; they shall abide therein." viii

But whosoever turns away from My Message, verily for him is a life narrowed down, and We shall raise him up blind on the Day of Judgment. ${ }^{\text {ix }}$ 
Man is created as a social being endued with free will, passion and emotions, which could either lead him to the highest or pull him down to the lowest ebb of creation. Humanity is but a big family with the same origin, mission and purpose. People have been divided into nations and tribes only to know each other, learn from each other, and cooperate at various levels in righteousness and piety. They are to explore the universe and within the framework rendered by revelation try to make their existence as convenient, comfortable and meaningful as possible, hence create virtuous cultures and civilizations. However, no sooner does this universal equilibrium become impaired and vitiated than man's relationship with God, his peers and the whole of the environment starts to degenerate.

Allah says about this:

O mankind! We created you from a single (pair) of a male and a female and made you into nations and tribes, that you may know each other (not that you may despise each other). Verily the most honoured of you in the sight of Allah is (he who is) the most righteous of you. And Allah has full knowledge and is well acquainted (with all things). ${ }^{\mathrm{x}}$

And among His Signs is the creation of the heavens and the earth, and the variations in your languages and your colours: verily in that are Signs for those who know. ${ }^{\mathrm{xi}}$

Islam with its monotheistic worldview champions that Muslims are brothers to each other and their similitude is like a wall whose bricks reinforces and relies on each other. They are like a solid cemented structure held together in unity and strength, each part contributing strength in its own way, and the whole held together not like a mass, but like a living organism. Muslims are furthermore related to each other in such a way that if one of them (a part of an organic and formidable formation called the Ummah, the Community) is troubled by a problem of any kind, the rest of the body parts will remain disturbed and restless until the matter became fairly solved.

\section{Islam and the Environment}

This Islamic unique perception of man and his position on earth necessitated the formation of a compelling and comprehensive view of the natural environment as well. This is so because man totally depends on nature for his survival. Also, nature is a ground for man's realization of his spiritual purpose on earth. Simply put, man is an integral part of the total natural setting. Man is nature himself, sustaining nature means sustaining his self, damaging nature means damaging his self and future prospects of a civilizational triumph. Owing to all this, Islam attaches a lot of importance to the subject of the environment and clearly expounding man's rights over it and his responsibilities towards it.

Islam teaches that the environment is part of the universal web of creation. Its role is two-fold: to worship its Creator (in ways suitable to it), and to be subjected to serve the exigencies of man, so that God's vicegerent can smoothly and undeterred carry out his honourable task of managing earth. 
The environment holds enormous potential and diversified resources meant only for the vicegerent of earth. They are to be seen as facilities which if rightly used facilitate each and every facet of man's fleeting stay on earth. The environment is further to be seen by man as an "ally" or a "partner", so to speak, in the execution of his earthly mission. After all, in order to create any piece of his built environment, which serves as a framework for his activities, man borrows diverse natural ingredients, such as space, water, clay, timber, stone and other substances, placing the newly created or built elements back into the existing natural contexts. The built environment is in many ways the natural environment which has been processed and manipulated.

According to a number of divine instructions, natural diversity and the forces of nature are to be the focus of man's exhaustive scientific and contemplative attention. Diversity in humans: skin colours, languages, attitudes and cultures, are to preoccupy the cognitive faculties of men as well, thus trying to find a link between it and the former. In all natural phenomena a great deal of wisdom lies and waits to be unearthed.

In Islam, man's rights over the environment are rights of sustainable use based on moderation, balance and conservation. The rights of the environment over man, on the other hand, are that it be safe from every misuse, mistreatment and destruction. Greed, extravagance and waste are considered a tyranny against nature and a transgression of those rights. ${ }^{\text {xii }}$

Islam teaches that all things have been created with purpose and in proportion and measure, both qualitatively and quantitatively. Nature's resources and forces are gifts granted by God to man. At the same time, however, the natural environment is a field for man's vicegerency mission. It is right there, while interacting with different aspects of the environment, that people clearly demonstrate how strong, or how deficient, their relationship with God is. So significant is man's relationship with the environment in Islam that in some instances such relationship is able to take precedence over other deeds of man, placing him on the highest or dragging him to the lowest level.

Furthermore, the environment stands for a source of man's spiritual enlightenment too, provided his treatment of it is apt and derived from divine teachings, in that the environment in its totality is an expression of God's presence, oneness, mercy and supremacy. By the power of reason and insight that has been accorded to him to subdue the forces of nature, man at the same time will be able to penetrate through and grasp properly nature's countless mysteries and phenomena. Consequently, this will lead to a considerable enhancement of his physical well-being, as well as to expediting the process of his spiritual advancement.

Finally, the environment, in a sense, participates in revealing Truth to man. It is in fact a revelation itself. Therefore, in addition to having the composed or written Qur'an (al-Qur'an al-tadwini) there is a cosmic or ontological "Qur'an" (al-Qur'an al-takwini) as well. Both revelations complement each other, as it were, in furnishing man with the necessary substance so as not to let him betray 
the trust of productively inhabiting the earth which he had wittingly accepted. It follows that those who fully submit to Divine Will and read, understand and apply the written Qur'an, they easily see upon the face of every creature "letters" and "words", or messages, from the "pages" of the cosmic Qur'an. For this reason are the phenomena of nature referred to in the Qur'an as signs or symbols (ayat), a term that is also used for the verses of the Qur'an. ${ }^{\text {xiii }}$

The following are some verses from the Qur'an on the discussed aspects of the environment:

Do not you see that to Allah prostrate all things that are in the heavens and on earth, - the sun, the moon, the stars, the hills, the trees, the animals, and a great number among mankind? But a great number are (also) such as unto whom the chastisement is justly due. And such as Allah shall disgrace, - none can raise to honor: for Allah carries out all that He wills. ${ }^{\text {xiv }}$

See you the seed that you sow in the ground? Is it you that cause it to grow, or are We the Cause? Were it Our Will, We could make it broken orts. And you would be left in wonderment... See you the water which you drink? Do you bring it down (in rain) from the cloud or do We? Were it Our Will, We could make it saltish (and unpalatable): then why do you not give thanks? ${ }^{\mathrm{xv}}$

O you people! Worship your Guardian Lord, Who created you and those who came before you that you may become righteous; Who has made the earth your couch, and the heavens your canopy; and sent down rain from the heavens; and brought forth therewith fruits for your sustenance; then set not up rivals unto Allah when you know (the truth). ${ }^{\text {xi }}$

And He has subjected to you, as from Him, all that is in the heavens and on earth: behold, in that are Signs indeed for those who reflect. ${ }^{\text {xii }}$

\section{The Importance of the Environment}

The implications of the concept of man as the vicegerent (khalifah) and his interaction with nature for architecture are both ideological and practical. To begin with, humans are not the only creatures that build. Many a creature that we classify low down the hierarchy of the animal kingdom, such as bees and ants, build elaborate structures. However, it has been suggested that it is awareness and imagination that single out humans as superior to other animals in architectural output. ${ }^{\text {xviii }}$ While the rest of creation act on the environment instinctively with no reasoning or training, man does the same willingly and at his own discretion. Since his actions are preceded with thinking and rationalizing, man clearly demonstrates through acts of building -- and through every other engagement of his -- his philosophy of, and outlook on, life's realities.

Based on his free will, awareness and imagination, man builds edifices in various shapes and sizes and with various function patterns in order to facilitate, nurture and motivate his copious life activities. In fact, such is of the fundamental things that distinguish man from other animate creatures that share this earth with him. The existence of man cannot be imagined without the existence of a built environment. The relationship between the two is causal, man always being the 
cause and built environment the effect. Therefore, no phase of man's presence on earth could be imagined to be devoid of building activities, irrespective of their scale, simplicity and sophistication.

This principle applies to all including the very first man and prophet on earth, Adam, who is said to have built the first House of worship, i.e., the al-Masjid alHaram or Baytullah (the House of God). Exactly forty years following the completion of the al-Masjid al-Haram, either Adam himself or some of his descendants were instructed to proceed to a designated location (later Jerusalem or Bayt al-Maqdis) and build there the al-Masjid al-Aqsa', the second mosque on earth. $^{\text {xix }}$

Ibn Khaldun ${ }^{\mathrm{xx}}$ rightly observed that building is a basis of civilization, and is of the most indispensable crafts which man ought to gain knowledge of:

This (architecture) is the first and oldest craft of sedentary civilization. It is the knowledge of how to go about using houses and mansions for cover and shelter. This is because man has the natural disposition to reflect upon the outcome of things. Thus, it is unavoidable that he must reflect upon how to avert the harm arising from heat and cold by using houses which have walls and roofs to intervene between him and those things on all sides. This natural disposition to think, which is the real meaning of humanity, exists among (men) in different degrees... xxi

Le Corbusier also remarked:

Architecture is one of the most urgent needs of man, for the house has always been the indispensable and first tool that he has forged for himself. Man's stock of tools marks out the stages of civilization, the stone age, the bronze age, the iron age. Tools are the result of successive improvement; the effort of all generations is embodied in them. The tool is the direct and immediate expression of progress; it gives man essential assistance and essential freedom also... ${ }^{x i i}$

Sinan (2006), the chief architect of the Ottoman golden age, said:

It is obvious and proven to men of intelligence and wisdom and persons of understanding and vision that building with water and clay being an auspicious art, the Children of Adam felt an aversion to mountains and caves and from the beginning were inclined to cities and villages. And because human beings are by nature civilized, they invented day-by-day many types of buildings, and refinement increased. ${ }^{\text {xiii }}$

While erecting buildings for himself, humans creates a wide range of facilities which are aimed at smoothing the progress of the realization of his heavenly purpose on earth. Buildings are thus subjected to serve together with their occupants an elevated order of things and meanings. They are to be both the means and ground for worship, which is man's principal task. Though serving him and his wants, God's vicegerent on earth always sees his buildings in an additional light, not seen by those who are bogged down with and blinded by fervently pursuing some lowly material gains. He sees them as an extension of the existing universal setting, God's physical realm, where all components, irrespective of their sizes, functions or positions, incessantly worship God. 
Buildings are thus seen as serving God rather than man. Their services to man even though genuine and real are rather relative. Because the whole universe constitutes a mosque (masjid) with everything in it, save a group of men and Jinns, voluntarily singing in unison God's praises and celebrating His glory with neither fatigue not boredom ever befalling them, Islamic architecture aspires to add to this exhilarating set-up. It aspires to endorse the divine spiritual standards and expands them to the spheres of human influences, thus making them more easily approachable and perceptible by more people with different interests and aptitudes. Hence, Islamic architecture apart from facilitating man's vicegerency mission also promotes as well as spawns people's interest in it.

When Mawlay Idris decided to build the city of Fas (Fez) in northern Africa having sketched the ground-plan of the city and before construction got underway, he recited the following prayer:

O my Lord! You know that I do not intend by building this city to gain pride or to show off; nor do I intend hypocrisy, or reputation, or arrogance. But I want You to be worshipped in it, Your laws, limits and the principles of Your Qur'an and the guidance of Your Prophet to be upheld in it, as long as this world exists. Almighty, help its dwellers to do righteousness and guide them to fulfill that. Almighty, prevent them from the evil of their enemies, bestow Your bounties upon them and protect them from the sword of evil. You are able to do all things. ${ }^{\text {xiv }}$

\section{Peaceful and Sustainable Coexistence between the Environment and Architecture}

The character of Islamic architecture is such that it tries its best to disguise its mundane naturalistic factors and features that may hinder a beholder's focus pointing in turn to a higher order of expression and meaning. The beholder's attention is directed towards the desired end by various ingenious artistic and structural ways and methods which are meant to yield an intuition of the real essence of the Transcendent and its divine infinity and perfection.

Since God is the Creator and Lord of everything, including man, He is the ultimate owner of everything. To God belongs everything in the universe. As far as man is concerned, though being elevated to the degree of God's vicegerent on earth and to whom all things have been subjected, he still possesses nothing. Everything around him has been loaned to him so that he in a responsible and unhindered manner can carry out his duties of vicegerency, no more than that. Even his very self, i.e., his life, man does not own. It belongs to his Creator, and if needed he is to sacrifice it for Him and His cause.

The Islamic notions of man as the vicegerent on earth and the natural environment as the field of man's vicegerency mission give Islamic architecture its conspicuous identity. It also creates in Muslims an unprecedented spiritualityloaded outlook on building activities so that the highest level of compatibility between buildings and their users exists. Islamic spirituality ensures that Islamic architecture and Muslims forge a productive, peaceful and sustainable alliance. They all originated from the same source and serve the same ontological purpose. 
No sooner does man come into this world than he sets out to display his inherent readiness to take from this world: to breath, to wear apparel, to drink, albeit without possessing anything, save his very self, to give away in return. Man is therefore born as an insolvent consumer. Not only does he own nothing, but he also remains forever short of enjoying a power of bringing into being anything without making use of the available raw materials and elements created for him in nature. Creating ex nihilo (from absolute nothingness), as a sign of genuine richness, sovereignty and might, is the right and power of God alone. Indeed, everything that man invents, conceives, concocts and creates is possible only thanks to the unbounded bounties and munificence from God which man only discovers, manages, processes, uses and reuses in different ways most convenient and efficient for him. The upshots of man's myriad civilizational pursuits on earth are never really his own possession and, as such, by no means could be solely utilized for returning the debt of creation and existence to God. Hence, being prudent, modest and grateful when dealing with God's gifts that grace existence, as well as when dealing with one's own accomplishments, are some of the virtues most appreciated, and the opposite is some of the vices most detested, in man. As far as the built environment is concerned, this translates as sustainability and sustainable development. God is thus to be acknowledged all the time and in every interest of man as the final end, as the ultimate object of all desire, as the ultimate source of all goodness, of all value. It is God Who makes every other good; He is the highest good for the sake of whom every good thing is good. ${ }^{\mathrm{xxv}}$

Allah says on this in the Qur'an: "They say: "Allah has begotten a son". Glory be to Him. Nay, to Him belongs all that is in the heavens and on earth: everything renders worship to Him. To Him is due the primal origin of the heavens and the earth. When He decrees a matter, He says to it: "Be," and it is." $\mathrm{xxvi}$

Do you not know that Allah's is the kingdom of the heavens and the earth, and that besides Allah you have no guardian or helper? ${ }^{\text {xxvii }}$

A revelation from Him Who created the earth and the high heavens. The Beneficent Allah is firm in power. His is what is in the heavens and what is in the earth and what is between them two and what is beneath the ground. ${ }^{\text {xxviii }}$

Allah explicitly says that he is the Creator and thus the owner of everything including people and whatever they are able to make. People's creations and possessions are in fact Allah's: "And Allah has created you and what you make."xxix

This philosophy is strikingly clear also in the field of architecture.

When building an edifice, the Muslim architect and structural engineer charged with the vicegerency are first and foremost concerned about how the end result of their efforts will stand out when juxtaposed with the existing universal setting, a result of heavenly artistry, in terms of both function and outward appearance: will it complement or contrast with it; will it go well with it, or will it appear as if something of a misfit, oddity, or even offensiveness; will it be sustainable? 


\section{Function}

Concerning function, the Muslim architect always exerts himself to ensure that a new structure serves a noble purpose, regardless of whether it is a mosque, school, dwelling, caravanserai, hospital, fountain, mausoleum, etc., whereby God alone is meant to be worshipped and adored. In this way, every new structure even though man-made yet it signifies, as it were, a conformation and even enhancement of the aura generated by the character and role of the natural world. Instead of standing alone amidst the marvels of God's creation, quite alien to them, a structure rather integrates itself with them as much as its plan, design and utility are able to suggest, identifying its status vis-à-vis the otherworldliness with that of the natural sensations around it.

Building materials and substances used in building processes are normally taken or "borrowed" from nature. The same materials heretofore belonged to the flawlessly executed universal web singing God's praises and celebrating His glory. Although they have been removed from their original contexts, the building materials from nature are still utilized for some other perfectly fitting goals related to man, thereby causing their intrinsic "holy pursuit" to remain unaffected or perturbed. As a result of the Muslim's restricted and controlled intervention in nature, only did the original condition and context of natural building materials and substances change, which is nevertheless expected, needed and in full accordance with God's universal will and plan. The inherent functions of those building materials and substances remain the same.

Before they are used in buildings, building materials from nature worship God in unison with the rest of nature's components. It is thus only fair that they are used in those buildings where God is worshipped as well, so that their unremitting acts are still performed in peace and without interruption. It sounds strange but it would be an act of injustice towards nature if some of its ingredients were used for erecting buildings wherein the authority of God will be disrespected and His words contravened. Besides, such a deed would also denote that a contribution toward upsetting the fine equilibrium in nature has been made. When the Prophet $(S A W)$ declared that "there is neither harming nor reciprocating of harm" he had in mind not only human beings but also the natural world with all its components. And surely, it is a form and degree of harm when the spiritual paradigms of nature are perturbed, just as it is harmful to abuse the physical aspects on nature's kingdom. The mentioned words of the Prophet $(S A W)$ implied, furthermore, that our built environments must be sustainable, that is, that they do not generate any harm to either people or their natural surroundings. A built environment is to be an asset, not a liability, to all of its users.

Surely, it stands to reason that as man is very much capable of perturbing the physical laws of nature by his actions, so is he in a position to get in the way of the covert aspects of nature's existence, as much as God allows it. Therefore, while creating buildings, that is to say, while creating frameworks and fields for their activities, God's vicegerents wish not to contravene any of the universe's spiritual laws and patterns. On the contrary, they wish to enhance them forever 
remaining on friendly terms with them. Certainly, a building can be either a "friend" or an "antagonist" to its animate and inanimate neighbours.

Indeed, as the vicegerent on earth endowed with free will, man while interacting with his surroundings, taking and giving, is in a position both to sustain and damage the existing natural equilibrium. It is up to what choice and life orientation and purpose man chooses. This is applicable not only to the physical aspects of the natural world, but also to the metaphysical or spiritual paradigms of whole existence. That is to say, Islam does not speak only about physical sustainability on earth, but also about a spiritual one throughout the realms of the vast universe, which God's vicegerents on earth must be fully aware of and must readily aim for. Such, it could be inferred, is the supreme goal of man's divine mission. Such, furthermore, is a clear measure of man's success or failure in his vicegerency undertaking.

\section{Form}

With regards the form of erected structures, the Muslim builder, powered with the spirit of tawhid and a desire to fulfill the will of a higher order or cause, always tries his best to make his edifices come into sight adhering to the existing spiritual paradigms of the natural environment. Nature is the perceptible sign of the Creator's will and presence, which is as evident in the most trivial as in the most splendid. Thus, every new component of built environment ought to become, in a way, a "sign" itself, lest they become irreconcilable with both nature and the spiritual and psychological disposition of their users. Islamic architecture is to be seen as a man-made "sign" amid the signs of God in nature.

Humans must live on friendly terms with nature, as much as such an arrangement is possible, beneficial and needed. Under no circumstances can man in any endeavor of his declare a war on the natural environment, because, on account of many a physical, mental and emotional weakness of his and his actual total dependence on the environment, man and nobody else is bound to emerge at all times as a dire loser. The natural environment is simultaneously an obstruction and help, and architects seek both to invite its aid and to drive back its attacks. If rightly conceived and seriously pondered, the placement and form of edifices in relation to their sites with arrangement of their axes and spaces may well be turned into a device for controlling natural light, ventilation, heating, cooling, insulation, acoustics, etc. The same philosophy is to be attached perhaps in a more forceful and compelling mode to the spiritual dimension of the relationship between the built and natural environment, as it concerns one's well-being in both this world and in the Hereafter. Because it goes along with the objectives of the Islamic Sharî'ah (Law), peaceful and harmonious coexistence with nature, in the spiritual sense of the term, was, furthermore, at the core of the Muslim's religious existence.

In view of the fact that Islamic architecture bears a strong spiritual impression and is one of the means for espousing the cause of Islam, it did not really always matter in the history of Islamic civilization who were the builders, planners and developers of many a project. What actually mattered was whether the ultimate 
roles and utility of such projects were justifying the time, effort and capital spent on them, as well as what their impact was on the existing state of the community and on its future progress. Although architecture as a profession was extremely important and honoured, architects, most of the time, have not been excessively venerated, neither by their patrons nor by the public. It was for this that on most of Islamic buildings no names of their builders were inscribed. If there was anything imprinted on them, then it was the date of their commencement or completion, or the name of the ruler or the patron. Except in cases of insincere undertakings, never were the architects, planners or developers concerned about promoting their name or status, about their position in history, about what some short-sighted people would say about their work, about how some members of the ruling elite would react during and after construction, and so forth.

This indicates that buildings in Islam are erected to serve together with their occupants the only Creator and Lord of the universe. As a result built structures in Islam were solely an attestation of God's oneness and greatness on this earth. Also, Muslim architects and structural engineers turned down a prospect of drawing attention to themselves, their careers and their works of art. They feared that such an act would somewhat impinge on and, in the worst scenario, debilitate the promotion of the idea of total spirituality underlining the total identity of Islamic architecture. Nothing was to stand between God and a building's users and observers. Through the planning and organization of spaces in buildings, through the handling of buildings' forms, through the methods and styles of ornamentation and beautification in buildings, and through the envisioned functions of buildings -- through all these channels and means Muslim architects and structural engineers go all-out to put on view the signs of the Creator's presence, infinite authority and greatness, on the one hand, and to display the signs of men's fragility, dependence and smallness, on the other. This way, every building in Islamic architecture is transformed into a kind of a house of God, baytullah, so to speak, a place of worship for the followers of the Prophet. ${ }^{\text {xxx }}$

\section{Conclusion}

Islam is a complete way of life. It values and teachings, together with the teachings of Prophet Muhammad $(S A W)$, whose primary task was to explain to mankind and put into practice the precepts of Islam, are universal and timeless. The significance of Islamic architecture is universal and permanent too, in that the philosophy that it embodies is the Islamic one. However, such is the nature of Islamic architecture that it is receptive to both advances in science and technology and the dictates of people's living conditions. When we talk about the need for restoring the role and status of Islamic architecture in the world today, we must pay attention to the causes that will invariably lead us to the desired effects. One of the most important causes, certainly, will be our proper understanding of Islam: its teachings, history and civilization, coupled with the Islamization of ourselves and our societies. 
In genuine Islamic architecture, utmost respect for the environment must be displayed and practiced. The way Islamic architecture is conceived, created and used confirms that there is a peaceful coexistence between people and the environment, and between the realms of natural and built environments. Islamic architecture is an environment conscious enterprise, realizing and then inviting and accommodating nature's advantages and also realizing and then repelling its disadvantages. In other words, at the core of Islamic architecture lies the notion of sustainability.

\section{Selected Bibliography}

1. Abd al-Hamid, "Exploring the Islamic Environmental Ethics." Ins. A. R. Aqwan (ed). Islam and the Environment. 39-69. New Delhi: Institute of Objective Study, 1997.

2. Al-Faruqi, Isma'il Raji Al-Tawhid: its Implications for Thought and Life. Herndon: International Institute of Islamic Thought, 1995.

3. Bahnassi, Afif. The Islamic Architecture and its Specificities in Teaching Curricula. http://www.isesco.org.ma/pub/Eng/Islarch/P2.htm

4. Beg, M.A.J (ed), Fine Arts in Islamic Civilization. Kuala Lumpur: The University of Malaya Press; 1981.

5. Bianca, Stefano. Urban Form in the Arab World. London; New York: Thames and Hudson; 2000.

6. Burckhardt, Titus. Art of Islam. London: World of Islam Festival Publishing Company Ltd; 1976.

7. Ibn Khaldun, The Muqaddimah. Vol. 2. Translated from the Arabic by Franz Rosenthal. London: Rotledge and Kegan Paul, 1987.

8. Le Corbusier. Towards a New Architecture. Translated from the thirteenth French edition with an introduction by Frederick Etchelles. Oxford: Reed Educational and Professional Publishing Ltd; 1989.

9. Moustapha, Ahmad Farid. Islamic Values in Contemporary Urbanism, (unpublished), paper presented at the First Australian International Islamic Conference organized by the Islamic Society of Melbourne, Eastern Region (ISOMER), 1986.

10. Nasr, Seyyed Hossein. "Islam and the Environmental Crisis." Ins. A. R. Aqwan (ed). Islam and the Environment. 5-20. New Delhi: Institute of Objective Study, 1997.

11. Necipoglu, Gulru (ed)., Sinan's Autobiographies, Five Sixteenth-Century Texts. Leiden: Koninklijke Brill NV, 2006.

12. Parker, Michael \& Richards, Colin. "Ordering the World: Perceptions of Architecture, Space and Time." In Architecture \& Order. London: Parker Michael \& Richards Colin (ed). Routledge, 1994. 
${ }^{\mathrm{i}}$ Stefano Bianca, Urban Form in the Arab World (London; New York: Thames and Hudson; 2000).

ii Afif Bahnassi, "The Islamic Architecture and its Specificities in Teaching Curricula" (http://www.isesco.org.ma/pub/Eng/Islarch/P2.htm).

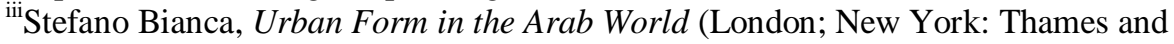
Hudson; 2000)

${ }^{i v}$ M.A.J. Beg, (ed), Fine Arts in Islamic Civilization (Kuala Lumpur: The University of Malaya Press; 1981)

${ }^{v}$ Burckhardt, Titus. Art of Islam (London: World of Islam Festival Publishing Company Ltd; 1976)

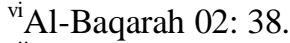

vii Al-Dhariyat 50: 56

viii Al-Baqarah 02: 39

${ }^{\mathrm{ix}}$ Ta Ha 20:124

xal-Hujurat, 49:13.

${ }^{x i}$ al-Rum, 30:22.

xii Abd-al-Hamid, "Exploring the Islamic Environmental Ethics." Ins. A. R. Aqwan (ed). Islam and the Environment(New Delhi: Institute of Objective Study, 1997), 39-69.

xiii Syed Hossein Nasr, "Islam and the Environmental Crisis." Ins. A. R. Aqwan (ed).

Islam and the Environment(New Delhi: Institute of Objective Study, 1997), 5-20.

xival-Hajj, 22: 18.

${ }^{\mathrm{xv}} \mathrm{Al}$-Waqi'ah,56: 63-70.

${ }^{\text {xvi }}$ Al-Baqarah, 02:21-22.

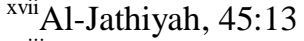

xviii Michael Parker, and Colin Richards, "Ordering the World: Perceptions of Architecture, Space and Time," In Architecture \& Order (London: Parker Michael \& Richards Colin (ed). Routledge, 1994)

${ }^{\mathrm{xix}}$ Sahih al-Bukhari, Tradition No. 3172.

${ }^{x x}$ Ibn Khaldun, The Muqaddimah. Vol. 2. Translated from the Arabic by Franz Rosenthal (London: Rotledge and Kegan Paul, 1987)

${ }^{\mathrm{xxi}}$ Ibid.

${ }^{x x i i}$ Le Corbusier. Towards a New Architecture. Translated from the thirteenth French edition with an introduction by Frederick Etchelles (Oxford: Reed Educational and Professional Publishing Ltd; 1989)

xxiii Gulru Necipoglu, (ed)., Sinan's Autobiographies, Five Sixteenth-Century Texts (Leiden: Koninklijke Brill NV, 2006)

${ }^{x x i v}$ Ahmad FaridMoustapha, Islamic Values in Contemporary Urbanism, (unpublished), paper presented at the First Australian International Islamic Conference organized by the [Islamic Society of Melbourne, Eastern Region (ISOMER), 1986]

${ }^{\mathrm{xxv}}$ Isma'il Raji al-Faruqi, Al-Tawhid: its Implications for Thought and Life (Herndon: International Institute of Islamic Thought, 1995)

${ }^{\text {xxi }}$ Al-Baqarah 02: 116, 117.

xxvii Al-Baqarah 02:107.

xxviii Ta Ha 20: 4-6.

${ }^{x x i x}$ Al-Saffat 37: 96.

${ }^{\mathrm{xxx}}$ Sahih al-Bukhari, Hadith No. 323 